\title{
Crowding-Out Effect Of Public Investment On Private Investment: An Empirical Investigation
}

Altin Gjini, State University Aleksander Moisiu Durres, Albania Agim Kukeli, University of New York Tirana, Albania

\begin{abstract}
This study's principal objective is to analyze the behavior of private investments in market economies in the New Emerging Economies (transition economies) in Eastern Europe. The main objective is to investigate the effect of public investment on private investments. Borrowing from neoclassical economics authors one expects to see a crowding out effect of public investment on private investments. The literature is divided and mixed at best at answering the question of what is the role of public investment in private investments. Our preliminary results show that while it can be true that there is a crowding out effect on private investment from public investments in the West, this is not the case looking at the East. There is a vast discussion on the effect of public investment on private investment at the firm level as well as aggregated at the country level. Among other factors recognized for such a discussion like uncertainty, imperfect competition, effectiveness, cost of capital that can bust or hinder private investment under the normal course of the country's economy this study looks at another angle. Western countries are diverse in terms of the size of government. The new emerging market economies on the East are struggling to get their economies to compete with western countries which have inherited better public institutions, infrastructure, and market conditions overall. A pool of selected countries, unbalanced panel data analysis, in Eastern European continent is examined over a period of time 1991-2009. The data are obtained from World Development Indicators (World Bank data base, 2010). Using pooled cross sectional analysis, the data confirm the structural break of private investment behavior between developing and developed countries. This is due to lack of market economy institutions, infrastructure, performance of the economy, and expectations.
\end{abstract}

Keywords: Private Investment; Public Investment; East European Countries; Crowding Out Effect; Panel data

\section{INTRODUCTION}

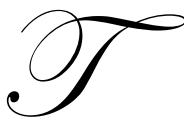

he crucial concern both for developed and developing countries of European continent, has been ensuring sustained positive economic growth. The neoclassical paradigm suggests that technology is the only factor that would maintain perpetually positive economic growth; it does not underscore the effect that spending on new capital, be it physical or financial, has on increasing of productivity at large and that of workers employed in respective industries, where these investments take place. It is interesting from both theoretical and empirical standpoint to research on the behavior of spending on new capital: investments. Policymakers, economist, and professional researchers have long been studying investment in varies facets to better understand its behavior, determinants, and its influence on economic growth.

In this study our main objective is to empirically estimate the effect of public investment on total private investment for a pool of Eastern European countries. It has been long recognized by theory and empirical studies that private investment is the main contributor in achieving economic growth (Solow, Lucas, and others). Countries that we have in our sample have undertaken ample efforts to refurbish their infrastructure they inherited from the command and control economic system. While the public investments have been geared towards upgrading existing 
infrastructure, establishing a new one that can serve the general public (schools, hospitals, bridges, etc), and management of government services, the private investments have been more on setting up productive facilities for private goods and services. These investments taken together have a determining effect on the economic growth of the country directly and indirectly. The direct effect is related with the contribution of new capital on nation's production process as capital enters directly in the country's production function. The indirect effect comes through increasing the amount of capital per worker, thus increasing workers' productivity.

Another indirect effect is closely linked with the possibility of public investment increasing the efficiency of private investments through creating a better infrastructure, increasing the amount of capital competing in the economy, facilitating the flow of goods and services, decreasing the cost of transportation, and cost of acquiring private capital; therefore increasing the profitability of private investment and increasing the aggregate amount of private investments. While this is well understood from the point of view discussed, it is not debated at all in any standard undergraduate macroeconomics textbook. Furthermore text book model predicts that the increase in public investment will crowd out the private investment.

Literature in this issue is inconclusive, it finds empirically that crowding out effect is present in the economy at times, or the opposite at some other times. This could be due to empirical methods employed, lack of computability power of data (especially in earlier studies when computability power was not at all near to what we have today), modeling and specification issues, or due to structural make up of national economies. The last one, as speculative as it may sound, can be justified in the grounds of two specific assumptions of general equilibrium model of crowding out result. First assumption being that the economy works at production possibility plane (or production possibility frontier in case of two goods, two factors of production simplification of an economy). Second has to do with the assumptions of perfect competition.

Factors that influence private investments are different, but public investment is one for which stand different opinions on how it influences the private investment - does it complements or compete the private investment? It is clear for everyone that public investment in infrastructure increases private investment, directly and indirectly by creating better conditions to do business. The results of the literatures suggest that public investment could crowd out private investment more often in developed economies, whereas in developing economies public investment is found more as complementary of private investment. In this study we analyze the effects of public investment on private investment in 11 East European countries by grouping them as developed and developing ${ }^{1}$ ones.

The argument used in the study is to let the data speak for themselves. A panel data analysis is employed for the purpose of estimating the marginal effect of public investment on private investment. A sample of eleven countries of Eastern European countries over a period from 1991-2009 is used in the analysis. In the next section we will present an extensive literature review in the issue discussed, which will be followed by a separate section on stylized facts, data and methodology. In this section we will discuss some findings from simple statistics on the countries selected, like growth rate. In this section also we will describe in detail the sample under empirical study including the data, their measurements, and limitation. Next we will set up the major hypothesis under discussion that comprises the development of major objectives of this research. The section will provide a detailed discussion of econometric model that will be used to estimate the relationship between private and public investments and the marginal effect of the last to the first. Lastly we will discuss data analysis, statistical tests, and some of the major findings. At the end there will be stated findings of this research, conclusions, and any further work to be extending the current paper.

\section{LITERATURE REVIEW}

There is a vast discussion about the effects of public capital investment on private investments. The question is, does public investment crowd in or out private investment? Four common approaches are used for modeling the investment in the existing literature, such as accelerator model, expected profit model, the neoclassical model and Tobin's q. One way to analyzing the effect of public investment on economic growth is based on the

${ }^{1}$ World Bank: Albania, Bulgaria, Latvia, Lithuania, Macedonia, Romania. 
neoclassical investment model in which public capital enters as a separate input and on the productivity measure derived from the production function. The Aschauer (1989.a) and (1989.b) reviewed the impact of the public capital stock on productivity (evidence from US annual and state level data) and the empirical results indicate that nonmilitary public capital stock, particularly on core infrastructure, is more important in determining productivity than is either flow of nonmilitary or military spending. Munnell (1992) analyzing the effects of infrastructure investment in economic growth stock concluded that in addition to provide immediate economic stimulus, public infrastructure investment has a significant, positive effect on output and growth. Also, the further work of Aschauer (1990) and Cashin (1995) conclude the same result that public capital influences positively economic growth.

Some other studies such as Holtz-Eakin (1994) and Evans and Karras (1994), find negligible role of public investment on productivity. Khan and Reinhart (1990), Khan and Kumar (1997) and Ang (2009) conclude that for developing countries the increase of the public investment influences positively economic growth, but less than contribution of private investment. Voss (2002) using data from both US and Canada suggests that for both countries there is no evidence to prove that public investment complements private investment, in fact innovations to public investment tends to crowd out private investment. Most of the literature that use the neoclassical approach arrive in conclusion that public capital investment has influence on the economic productivity but this factor is not a major one.

Another way that is used in analyzing the effect of public investment in economic prosperity is that of accelerator model, which uses private investment that incorporate public investment in order to point out the direct effect of public investment on private investment and also its indirect effect on economic growth through its effect on private investment. The conclusion that public investment has positive effect on private investment has been supported by studies such as Ramirez (1994) for Mexico, Odedokun (1997) for forty-eight developing countries and Ramirez (2000) for a panel of Latin American countries. Other works such as Blejer and Khan (1984) for a panel of developing countries conclude that public infrastructure crowd in private infrastructure and public non infrastructure investment crowds out private investment. Some other literature such as Way and Wong (1982) for five developing countries and Nazmi and Ramires (1997) suggest that public investment crowd out private investment. Erden and Holcombe (2005) for nineteen developing countries and twelve developing countries suggests that public investment crowd in private investment for developing countries and crowd out private investment for developed countries. The literatures suggest different results on the effect of the public investment on private investment.

Some of the factors that influence private investment sector are described in the different literature. The most important factor is public investment and especially public infrastructure investment. Blejer and Khan (1984), Aschauer (1989a, 1989b), Munnell (1992) and Ramirez (1997), conclude that public infrastructure investment has positive effects on private investment. Erden and Holcombe (2005) suggest that public investment crowd in private investment in developing countries and crowd out in developed countries. Ang (2009) analyzing the determinants of private investment in Malaysia suggest that public investment have a complementary effect on private investment. Cavallo and Daude (2011) suggest that in average for 116 developing countries the public investment crowd out private investment. The case of public infrastructure investment is clear from every one because as results of better infrastructure enhances private capital productivity, raising its rate of return and encouraging more private investment. If we see the public investment from the inventories perspective, in this case both public and private investment compete for the same recourses, the public capital acts as a substitute for the private capital and crowd out the private investment.

Credit availability is another important factor that influences the level of private investment, which is supported by Wai and Wong (1982), Blejer and Khan (1984), Ramirez (1994), Ghura and Goodwin (2000), Erden and Holcombe (2005), Ang (2009), Cavallo and Daude (2011). The limited financial resources for private investment are more present in developing countries. Increasing the availability of credit has positive effect on private investment. Cost of capital is another factor that effects public investment as concluded by Blejer and Khan (1984). The decrease of cost of capital also influences positively the private investment as suggested by Ghura and Goodwin (2000). Change in real gross domestic product is another factor that influences the private investment suggested by Ghura and Goodwin (2000), Ang (2010), Blejer and Khan (1984). 
Uncertainty is another factor that influences the level of private investment. Studies such as Hartman (1972) and Abel (1983) show that increase in uncertainty brings about increase in the expected value of marginal revenue products of capital and as a result increase investment. Hartman (1985) analyzing the effect of uncertainty about future levels of government spending has on private investment suggests that increase uncertainty tend to increase the private investment. Ang (2010) analyzing the determinants of the private investment in Malaysia suggests that macroeconomic uncertainty exerts a negative effect on investment climate in the private sector. Kumo (2006) investigating the time varying uncertainty on aggregate private fixed investment in South Africa conclude that, over all, time varying macroeconomic uncertainty significantly reduces private fixed investment.

The main objective of this study is to analyze the effect of public investment on private investment in 11 East European Countries in context of developing countries and also developed countries. Factors that are taken in consideration for achieving our objective are real gross public investment, real gross private investment, bank credit, inflation rate, and cost of capital. Data are obtained from world Development Indicators (World Bank data base, 2011) for the period $1991-2009$.

\section{STYLIZED FACTS, DATA, AND METHODOLOGY}

Data on the countries chosen to be represented in this study reveal that they constitute good part of Eastern European economy. After a harsh period of command and control economy, now they have emerged as fully fledged market oriented economies. Some of them, like Croatia, Estonia, Poland, Slovak Republic, and Slovenia, once under dictatorial regimes and centralized planning, have moved up to developed countries. The most striking feature of these economies is their economic growth last twenty years. The table below shows these countries performance in the last two decades (Figure 1). The figure shows clear the so called struggle that countries have gone through keeping up with many reforms they had to undertake to shift their economies from central planning system to market price system. Albania, Poland, Slovak Republic, Slovenia, and Estonia have managed to retain an annual economic growth above 1.5 percent. While other countries in the sample have performed at levels less than 1.5 percent annual economic growth. The lowest annual growth rate is in Macedonia.

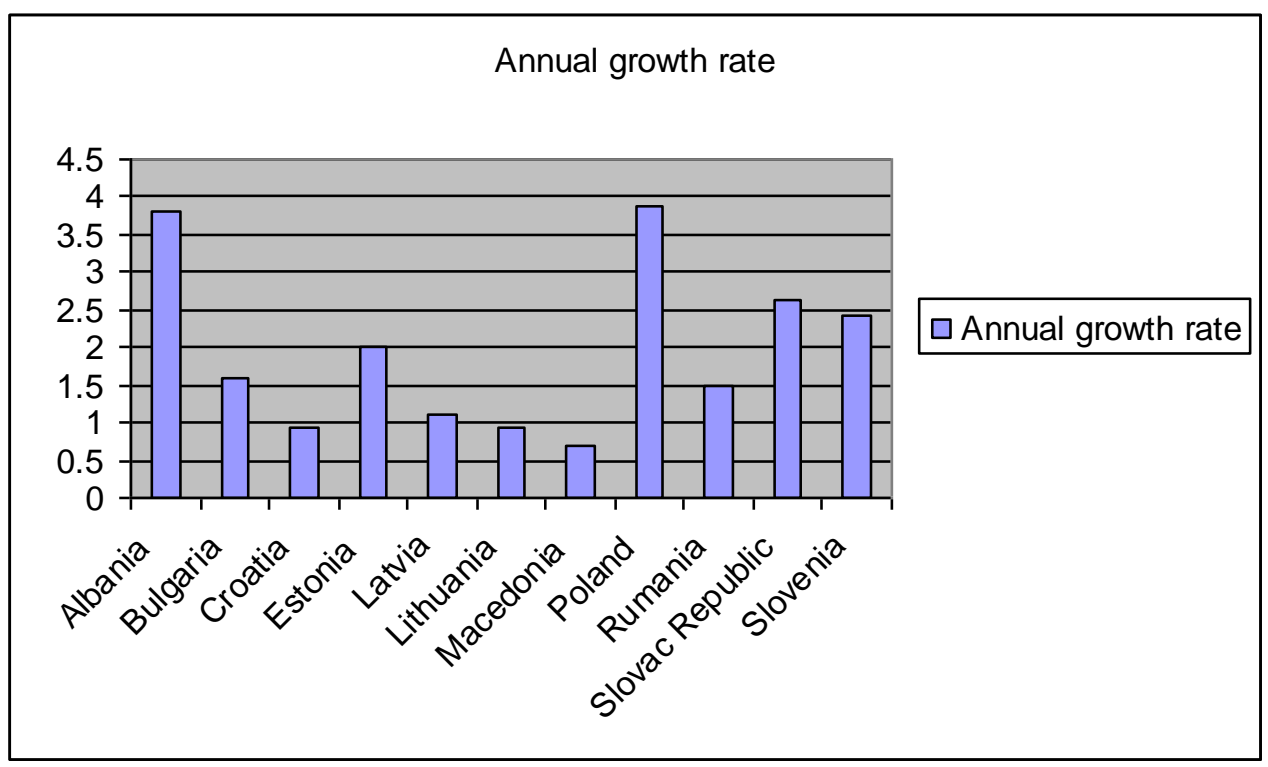

Figure 1: Annual growth rate averaged, period 1991-2009²

\footnotetext{
${ }^{2}$ World Development Indicators, author's calculations. 
The sample is comprised of eleven countries. These are: Albania, Bulgaria, Croatia, Estonia, Latvia, Lithuania, Macedonia, Poland, Rumania, Slovak Republic, and Slovenia. Following the classification, based on their GDP per capita the sample can be divided into two groups. In developing countries, which are Albania, Bulgaria, Rumania, Latvia, Lithuania, Macedonia; and in developed countries which are Croatia, Estonia, Poland, Slovak Republic, and Slovenia. Data are taken from WDI (World Bank) for a period of 19 years (1991-2009).

The following variables and their units of measurements are taken from the above source: Ip $=$ real gross private investment (constant 2000 US million dollar), Ig = real gross public investment (constant 2000 US million dollar), $\mathrm{r}=$ real interest rate $(\%), \mathrm{B}=$ domestic credit provided by banking sector (\% of GDP), $\mathrm{P}=$ consumer price index $(2005=100)$ as a measurement of inflation. Real gross investment for private and public sector are authors' calculation based on the available data on real GDP, and percentage of real GDP in investment on private and public sector. The methodology used in this study is that of panel data regression analysis. More specifically it treats the panel data as stacked cross section units, where units are respective countries. The Weighted Least Squares (WLS) econometric model is used due to the fact that countries differ in many respects and one would find it as plausible to think that space intercept is specific for each of the countries included in the sample.

\section{HYPOTHESES AND THE ECONOMETRIC MODEL}

The study aims at empirical estimation of the relationship between private investment and public investment, the effect that public investments have on private investment, the effect of bank credit available to private sector on private investments, the effect of real interest rate (as the cost of capital) on private investment, the effect of inflation on private investment, and whether there is a structural break between developing and developed countries on these estimates. For this purpose five following hypothesis will be stated, tested, and discussed in sequential comportment in the section below.

H1: Given the fact that all countries in our sample do not comply with efficiency (production possibility frontier-like efficiency), are still far away from perfect competition economies, and have been heavily involved in public investment to refurbish their public infrastructure, we would expect to find a positive relationship between private and public investment.

H2: There is a negative relationship of real interest rate on the private investment. This can simply be understood, if we can think of real interest rate as the real cost of undertaking an investment activity. One would expect that as the cost of acquiring capital (e.g. real interest rate) increases, potential investors would withdraw from their projects. This will result on a decrease on the level of private investments. Therefore we would expect the marginal effect of real interest rate on private investment to be negative.

H3: There is a positive marginal effect of bank credit available to private sector and private investment. The countries included in our study have faced multifaceted challenges in transforming their economies. Due to problems with collateral, information system, public expectations and others the banking system had much to accomplish to be able to provide funds for private investment. On the other hand bank credit available to investors is crucial in providing for entrepreneurial spirit of young and foreign investors wanted to set up their new businesses in these countries.

H4: There is a negative marginal effect of inflation on the private investment. This is due to two effects that inflation will have on private investment. First effect will work through the expectations that business people form based on the inflation. These expectations will enter into the investor's objective function as an addition to the future cost of investment. Second effect enters the investor's objective function as a policy variable. Investors see inflation as a measurement of policy soundness that governments and central banks undertake. Therefore we would expect this marginal effect to be negative.

H5: There will be a structural break on the data in relation with the effect of public investment on private investment. This structural break is due to the economic differences among countries included in this study. The easiest way to estimate this structural break is to divide the sample in two major groups: developing and developed countries. We expect the marginal effect of public investment on private investment is different for these two different groups. 
This study will employ two econometrics models, which will be estimated using panel data analysis of eleven randomly selected East European countries for period 1991-2009. The first model (call it Model I) is:

$$
I p=b_{0}+b_{1}(I g)+b_{2}(r)+b_{3}(B)+b_{4}(P)+e
$$

and the second model (call it Model II) is:

$$
I p=b_{0}+b_{1}(I g)+b_{2}(r)+b_{3}(B)+b_{4}(P)+b_{5} I g-D+e
$$

We are interested in estimating all coefficients in both models. For this purpose this study employs the method of fixed effects. The table 1 shows the results of both models. A comparison of both models shows that they have striking explanatory power. The adjusted $\mathrm{R}$ square is high and it increases when dummy variable is included (second model) to measure the differentiated effect of public investment in private investment for developing and developed countries.

Table 1: Summary of econometric results (model I and II)

\begin{tabular}{|l|c|c|}
\hline \multicolumn{1}{|c|}{ Variables } & Model I & Model II \\
\hline Ig & 4.65296 & 10.0329 \\
& $(0.370173)^{* * *}$ & $(0.674864)^{* * *}$ \\
\hline $\mathrm{R}$ & -112.023 & -56.8570 \\
& $(123.302)$ & $(66.1563)$ \\
\hline B & 385.004 & 73.1534 \\
& $(62.9673)^{* * *}$ & $(34.4516) * *$ \\
\hline P & -312.808 & -106.470 \\
& $(55.9007)^{* * *}$ & $(35.4349) * * *$ \\
\hline Ig_D & - & -6.89962 \\
& 0.774984 & $(0.672394)^{* * *}$ \\
\hline Adjusted R & & 0.778726 \\
\hline
\end{tabular}

The estimated equations for both models are:

$$
\begin{aligned}
& I p=b_{0}+4.66 \mathrm{Ig}-112.02 r+385 B-312.81 P+e \\
& I p=b_{0}+10.03 \mathrm{Ig}-56.86 r+73.15 B-106.47 P-6.9 \mathrm{Ig} \cdot D+e
\end{aligned}
$$

Where $\mathrm{D}=0$ for developing countries and $\mathrm{D}=1$ for developed countries. The estimated marginal effects shows that signs of the effects are in line with hypothesis and with what the economic theory suggests (model I). It is shown that there is no crowding out effect of private investment by public investments. Furthermore there is a 4.66 billion dollar increase in private investment for every billion dollar increase in public investments (numbers are in 2000US dollar). This marginal effect decreases for developed countries from 4.66 to 3.24 billion dollars. It is interesting to see that crowding out effect diminishes as country moves up in the ladders of development. Not clear it suggests that developed countries get closer to "production possibilities plane" due to increase in efficiency and in competitiveness. We could speculate that it might be due to enhancing effect of institutions on private and public investments as countries develop. What is not clear from the above regression results is that estimated coefficients are not the same and it needs further work. The problems with specification model should be addressed in a future research.

\section{CONCLUSION}

This study has estimated from the empirical point of view the so called crowding out effect of public investment in private investment. Pooled cross sectional data analysis of eleven selected East European countries 
has been used to estimate the marginal effect of public investment, bank credit available to private investors, inflation, and real interest rate on private investment. The results show that there is no crowding out effect of public investments on private investments. The marginal effect of public investments on private investments is positive and it diminishes as country moves from less developed to more developed county. Results are as we expected though striking if compared with some of the studies done on this issue. Further research should be extended on model specification and refining the theoretical underpinning of such "faked tale".

\section{AUTHOR INFORMATION}

Altin Gjini, PhD Candidate. MSc Gjini is instructor of economics and finance at University "Aleksander Moisiu" Durres and in his final stage of doctoral program at the same university. He works full time at the Albanian General Directory of Customs and has participated in national and international conferences. His main resaerch is foucused on macoreconomics policies with respect to investment, consumption, VAT, etc. E-mail: altin_gjini@yahoo.com

Prof. Dr. Agim Kukeli, PhD. Dr. Kukeli is currently a full time professor of Economics and finance at University of New York Tirana (a university that colaborates with SUNY Empire State College, University of Greenwhich, University of Bolton, and Institute Universitar Kurt Bosch). He has an MA and PhD degrees in economics from Colorado State University. He has been Teaching Instructor at Colorado State University for three years, Assistant Professor at Colorado Mesa University for two years, founding rector and elected rector of University "Aleksander Moisiu" University. His resaech interst is mainly in internalional economics, game theory, and econometric application of policy evaluations. E-mail: akukeli@unyt.edu.al. Corresponding author.

\section{REFERENCES}

1. Abel Andrew B. 1983, Optimal investment under uncertainty, American Economic Review 73:228-33.

2. Agénor Pierre - Richard, 2010, A theory of infrastructure- led development, Journal of Economics Dynamics \& Control 34: 932-950.

3. Aschauer David A. 1989, Is public expenditure productive? Journal of monetaryEconomics 23: 177-200.

4. Aschauer David A. 1989, Does public capital crowd out private capital? Journal of Monetary Economics 24 (2): 171-188.

5. Aschauer David A. 1990, Why is infrastructure important? Is there a shortfall in public capital investment? Conference Series of Federal Reserve Bank of Boston.

6. Blejer Mario, and Khan Mohsin, 1984, Private investment in developing countries: its importance, and how it is affected by public policy, Finance and Development, 21(2): p 26

7. Cashin Paul, 1995, Economic growth and convergence across the seven colonies of Australia: 1861-1991, Economic Record, 71: 213: p 132.

8. Cavallo Eduardo, and Daude Christian, 2011, Public investment in developing countries: A blessing or a curse? Journal of Comparative Economics 39: 65-81

9. Douglas Holtz-Eaking, 1994, Public-Sector capital and productivity puzzle, The Review of Economics and Statistics, Vol 76: nr.1 pp 12-21.

10. Egbert J. Strum and Hann de Jakob, 1995, Is public expenditure really productive? Economic Modeling 12(1): 60-72

11. Edward F. Buffie, 1995, Public investment, private investment, and inflation, Journal of Economic Dynamics and Control 19: 1223-1247

12. Evans, Paul and Karras, 1994, Are government activities productive? Evidence from a panel of U.S. states, Review of Economics and Statistics, 76.1: 1.

13. Ghura, and Goodwin, 2000, Determinants of private investment: a cross-regional empirical investigation, Applied Economics, 32, 1819-1829.

14. Girard Jacques, Gruber Harold, and Hurst Chris, 1995, Increasing public investment in Europe: some practical considerations, European Economic Review, 39: 731-738.

15. Hartman Richard, 1985, Uncertainty in future government spending and investment, Quarterly Journal of Economics, Vol 100, Iss 4: pp1339-1347

16. Hartman Richard, 1972, The effects of price and cost uncertainty on investment, Journal of Economic Theory, 5: 258-266 
17. James B Ang, 2010, Determinants of private investment in Malaysia: what causes the postcrisis slumps? Contemporary Economic Policy, Vol 28. Nr 3: 378 - 391

18. Khan Mohsin and Reihnart Carmen, 1990, Private investment and economic growth in developing countries, World Development 18 (1): 19-27.

19. Khan Mohsin and Kumar Manmohan, 1997, Public and private investment and the growth process in developing countries, Oxford Bulletin of Economics \&Statistics 59 (1): p59.

20. Kumo Wolassa L, 2006, Macroeconomic uncertainty and aggregate private investment in South Africa, South African Journal of Economics, Vol 74:2

21. Laopodis Nikiforos, 2001, Effects of government spending on private investment, Applied Economics 33 (12): p 1563

22. Lutfi Erden and Randall Holcombe, 2005, The effects of public investment on private investment in developing economies, Public Finance Review, Vol 33 nr5, pp575-602.

23. Mitra Pritha, May 2006, Has government investment crowded out private investment in India? American Economic Association, Vol 96, No2, pp 337-341.

24. Munnell. H Alicia, 1992, Infrastructure investment and economic growth, The Journal of Economic Perspectives, Vol 6 nr4: pp189-198

25. Nadiri M. Ishaq and Manuneas Theofanis P. February 1994, The effects of the public infrastructure and R\&D capital on the cost and the productivity of the US manufacturing industries, Review of Economics and Statistics, Vol 76 issue (1), p22, 16p.

26. Nazmi Nader and Miguel D Ramires, 1997, Public and private investment and economic growth in Mexico, Contemporary Economic Policy. 15. 1: 65.

27. Odedokun, 1997, Relative effects of public versus private investment spending on economic efficiency and growth in developing countries, Applied Economics 29. 10: pp 1325 - 36.

28. Pereira Alfred and Sagales Oriol, 2001, Infrastructure and Private Sector Performance in Spain, Journal of Policy Modeling 23: 371-384.

29. Ramirez Miguel, 1994, Public and private investment in Mexico, 1950-90: An empirical analysis, Southern Economic Journal 61 (1): 1-17.

30. Ramirez Miguel, 2000, The impact of public investment on private investment spending in Latin America: 1980-95, Atlantic Economic Journal 28 (2): 210-25.

31. Seitz Helmut, 1994, Public capital and the demand for private inputs, Journal of Public Economics 54: 287307.

32. Ramirez Miguel D. 1994, Public and private investment in Mexico, 1950-1990: an empirical analysis, Southern Economic Journal, 61.1: 1.

33. Ramirez Miguel D, 2000, The impact of public investment on private investment spending in Latin America: 1980-1995, Atlantic Economic Journal, 28 (2): 210-25.

34. Way and Wong, 1982, Determinants of private investment in developing countries, Journal of Development Studies, Vol 19, Issues 1: p 19.

35. Voss M. Graham, 2002, Public and private investment in the United States and Canada, Economic modeling 19: 641-664. 